\title{
PREVALENCE OF MYCOBACTERIUM TUBERCULOSIS AMONG PROFESSIONALS IN A UNIVERSITY HOSPITAL, MATO GROSSO DO SUL, 2004
}

\author{
Sandra Maria do Valle Leone de Oliveira ${ }^{1}$ \\ Michael Robin Honner ${ }^{2}$ \\ Anamaria Mello Miranda Paniago 3 \\ Eliana Setti Albuquerque Aguiar $^{3}$ \\ Rivaldo Venâncio da Cunha ${ }^{3}$
}

Oliveira SMVL, Honner MR, Paniago AMM, Aguiar ESA, Cunha RV. Prevalence of mycobacterium tuberculosis among professionals in a university hospital, Mato Grosso do Sul, 2004. Rev Latino-am Enfermagem 2007 novembro-dezembro; 15(6):1120-4.

Several studies have demonstrated an elevated prevalence amongst professionals of mycobacterium tuberculosis, both in the rate of infections and illness. This study was carried out in a School Hospital in Campo Grande, MS, Brazil, aiming to establish the prevalence of infection with Mycobacterium tuberculosis. The results of the analysis of 194 subjects showed an overall positivity for the tuberculin test of $38.7 \%$. There was a correlation with smoking ( $p=0.01$, $R P=1.72$ (1.20-2.45- Yates's correction). The conclusion is that the establishment of a program of tuberculin screening jointly with the implementation of interventions is necessary in order to reduce the risk of nosocomial transmission.

DESCRIPTORS: tuberculin test; prevalence; health personnel; epidemiology

\section{EXISTENCIA DE LA INFECCIÓN TUBERCULOSIS ENTRE PROFESIONALES DE UN HOSPITAL UNIVERSITARIO EN MATO GROSSO DO SUR, 2004}

Varios estudios han demostrado la alta prevalencia de infección tuberculosis, y también de la propia enfermedad, entre los profesionales de salud. Este estudio, realizado en un Hospital Universitario ubicado en la ciudad de Campo Grande-MS, tuvo como objetivo conocer la existencia de la infección causada por el Mycobacterium tuberculosis. En el análisis de 194 personas, fue encontrada la existencia de la prueba tuberculinilla del 38,7\%. Fue observada una asociación con el tabaquismo ( $p$ 0,01, y RP 1,72 (1,20-2,45) corregido por yates). Concluimos que es necesario un programa de selección tuberculinilla de rutina para acompañar el viraje tuberculínico, junto a intervenciones para reducir el riesgo de transmisión nosocomial.

DESCRIPTORES: prueba de tuberculina; prevalencia; personal de salud; epidemiología

\section{PREVALÊNCIA DA INFECÇÃO TUBERCULOSA ENTRE PROFISSIONAIS DE UM HOSPITAL UNIVERSITÁRIO}

Vários estudos têm demonstrado prevalência elevada de infecção tuberculosa, tanto quanto de adoecimento, entre os profissionais de saúde. Este estudo, realizado em um Hospital Universitário, situado na cidade de Campo Grande, MS, teve como objetivo conhecer a prevalência de infecção pelo Mycobacterium tuberculosis entre esses profissionais. Na análise de 194 indivíduos, encontrou-se prevalência global de positividade da prova tuberculínica de 38,7\%. Observou-se associação com o tabagismo (p 0,01, e RP 1,72 (1,20-2,45) - corrigido por Yates). Concluise que é necessário estabelecer um programa de triagem tuberculínica de rotina para acompanhamento de viragem tuberculínica, juntamente, com a instituição de intervenções para reduzir o risco de transmissão nosocomial.

DESCRITORES: teste tuberculínico; prevalência; pessoal de saúde; epidemiologia ${ }^{1}$ RN, MS, Infectious Diseases Unit, e-mail: sandraleone@nin.com.br; ${ }^{2}$ PhD Professor, e-mail: mrhoner@terra.com.br; ${ }^{3}$ Adjunct Professor, e-mail:
anapaniago@terra.com.br, e7aguiar@uol.com.br, rivaldo_venancio@brturbo.com.br. Mato Grosso do Sul Federal University, Brazil 


\section{INTRODUCTION}

Tuberculosis infection affects one third of the planet's population and was considered a world emergency by the World Health Organization (WHO) in 1993. According to present estimates, there exist around eight million cases and two million deaths due to tuberculosis, circumscribed to 22 countries. Brazil occupies the $15^{\text {th }}$ place, notifying around 80 to 90 thousand new cases per year, corresponding to the $9^{\text {th }}$ reason for hospitalization in the Single Health System and the $4^{\text {th }}$ cause of mortality due to infectious disease ${ }^{(1-2)}$.

Besides the increased incidence of tuberculosis in the general population, a change is occurring in the illness' natural history in special population groups, particularly in hospital environments, where a high prevalence of individuals carrying comorbidities is found, such as infection by the Human Immunodeficiency Virus (HIV), cancer and diabetes mellitus. These comorbidities might favor the increase of non-isolated hospital time until the infection is diagnosed, thus propagating the microorganism within these environments ${ }^{(3)}$.

Several studies indicate a major risk among professionals who act in health care institutions and alert that factors like service time, professional category and respiratory protection are relevant in transmission. The diagnosis and lab corroboration delay, as well as the precariousness of infrastructural conditions, the inexistence of isolation beds and a work process that involves a long work period, culminating in double employment, stress and often work overload, are also mentioned as related factors ${ }^{(2-4)}$.

In some regions, a large number of tuberculosis cases can be observed, attended and diagnosed in hospital environments, as the patients usually turn to these places for diagnosis and treatment, increasing the probability of resistant TB cases, and thus justifying tuberculin screening among health professionals in hospital units ${ }^{(1,5)}$.

The discovery of the purified protein derivate (PPD), as a test capable of identifying individuals infected by the Kock bacillus, contributed to research advancements within potential tuberculosis risk groups. The tuberculin test is frequently used to diagnose the latent form of tuberculosis, enabling evaluation studies of tuberculosis infection risk rates at each health care institution, and consequently the screening and accompaniment of health professionals, being considered a new case prevention and detection strategy ${ }^{(1-2,5-6)}$.

This study aimed to estimate the prevalence of infection by Mycobacterium tuberculosis in professionals who develop administrative, care and hygienization activities at the University Hospital of Mato Grosso do Sul Federal University (UFMS), trying to relate tuberculin test positivity with possible risk factors.

\section{METHODS}

Place of Study

The study was carried out at the UFMS (HU/ UFMS) University Hospital, a large hospital of high complexity, which offers a care program for patients with tuberculosis diagnoses and is a referral institution in the state for infectious diseases like HIV/AIDS.

Study design

The study was performed between 04/01 and 09/30/2004 and the population consisted of HU/UFMS workers, who had direct or indirect contact with patients during the hospitalization process in the intrahospital environment, or with their secretions in the lab environment.

Selected civil servants who accepted to take part in the study were included, after having received verbal information on the purposes and methodology of the research. This acceptance was given in writing. They completed a standard form for data collection on the study variables and were submitted to the tuberculin test for the first time. When negative, however, they were submitted to a second application within the next 1 - 3 weeks for booster effect analysis.

Based on epidemiologic studies, which estimate a frequency of $25 \%$, a prevalence sample estimate of $30 \%$ was used for calculation purposes ${ }^{(4)}$.

The hospital employed 1218 civil servants. The sample consisted of 194 workers, calculated on the basis of EpiInfo 2003, version 3.3.2, with a significance level of $8 \%$. Probabilistic sampling was used, stratified by activity groups: administrative, care and hygienization. An additional $20 \%$ was inserted to correct for losses. 
Workers who presented a history of tuberculosis, who had used tuberculostatic agents in the past, and/or were passing through immunosuppressant therapy, as well as those who did not agree in participating after reading the free and informed consent term, were excluded.

The Mantoux technique was used for tuberculin testing. Appropriate syringes $(1 \mathrm{ml})$ and $13 \times 4.5 \mathrm{G}$ discarding needles for intradermal administration of $0.1 \mathrm{ml}$ PPD (purified protein derivate) in the left interior forearm of each professional. After 72 hours, the author, who had been trained and qualified for appliance and lecture at a Tuberculosis Reference Center, performed a lecture for evaluation of papule formation with well delimited $\operatorname{borders}^{(2,6)}$.

Pparticipants whose tuberculin test presented an induration e" $10 \mathrm{~mm}$ were considered as infected, evaluated within 72 hours, and the booster effect was tested after 1-3 weeks $^{(2,7)}$.

The tuberculin was a PPD Rt 23 derivate (supplied by the Prof. Hélio Fraga Filho Reference Center/MS, produced at the Statem Serum Institut, Copenhagen/Denmark, through the Ministry of Health); five-ml vials were available.

All individuals who presented a strongreacting tuberculin test were forwarded to a pneumologist and/or infectious disease specialist at the Profa. Esterina Corsini Day Hospital.

Form

A form was used, elaborated by the Hospital Tuberculosis Control Program of Rio de Janeiro's Federal University ${ }^{(7)}$.

Ethical Aspects

The present study was approved by UFMS' Ethics Committee for research involving human beings.

\section{RESULTS}

Tuberculosis infection prevalence among the 194 participants was $38.7 \%$. No statistically significant difference was observed among the activity groups.

The global and activity tuberculin test positivity among the 194 participants is shown in Table 1 .
Table 1 - Professional distribution per category, according to tuberculin test positivity, Maria Aparecida Pedrossian University Hospital Nucleus /UFMS, 2004

\begin{tabular}{lcccc}
\hline \multirow{2}{*}{ Variables } & \multicolumn{2}{c}{ Tuberculin test } & \multirow{2}{*}{ Total } & P \\
& Strong reactor $(\mathbf{n}=\mathbf{7 5})$ & Non reactor $(\mathbf{n}=\mathbf{1 1 9})$ & & \\
\hline Administrative & $20(32.3)$ & $42(67.7)$ & $62(100.0)$ & 0.15 \\
Hygienization & $24(50.0)$ & $24(50.0)$ & $48(100.0)$ \\
Care & $31(36.9)$ & $53(63.1)$ & $84(100.0)$ & \\
\hline Total & $\mathbf{7 5 ( 3 8 . 7 )}$ & $\mathbf{1 1 9 ( 6 1 . 3 )}$ & $\mathbf{1 9 4 ( 1 0 0 . 0 )}$ \\
\hline
\end{tabular}

$p \leq 0.05$ significant statistic difference, Yates correction for continuity chisquare test

Sociodemographic factors and tuberculin test positivity were distributed according to Table 2 .

Table 2 - Professional distribution per gender and age, according to tuberculin test positivity, Maria Aparecida Pedrossian University Hospital Nucleus /UFMS, 2004

\begin{tabular}{lccc}
\hline Variables & \multicolumn{2}{c}{ Tuberculin test } & \multirow{2}{*}{ Total } \\
\cline { 3 - 4 } & Strong reactor $(\mathbf{n = 7 5 )}$ Non reactor $(\mathbf{n = 1 1 9 )}$ & \\
\hline Gender & & & \\
$\quad$ Male & $27(42.9)$ & $36(57.1)$ & $63(100.0) 0.90 .50$ \\
Female & $48(36.6)$ & $83(63.4)$ & $131(100.0)$ \\
Age & & & \\
$<38$ years & $32(33.7)$ & $63(66.3)$ & $119(100.0) 0.00 .21$ \\
$>38$ years & $43(43.4)$ & $56(56.6)$ & $75(100.0)$ \\
\hline
\end{tabular}

$p \leq 0.05$ statistically significant difference, Yates correction for continuity of chi-square test

Social habits according to tuberculin test positivity are described in Table 3, with statistical significance regarding professionals with nicotine addiction $(p=0.001)$ and relative risk of $1.72(1.20$ 2.45).

Table 3 - Subject distribution according to Cage, nicotine addition and tuberculin test positivity, Maria Aparecida Pedrossian University Hospital Nucleus /UFMS, 2004

\begin{tabular}{cccccc}
\hline Variable & $\begin{array}{c}\text { Strong reactor } \\
(\mathbf{n}=75)\end{array}$ & $\begin{array}{c}\text { Not reator } \\
(\mathbf{n}=119)\end{array}$ & Total & $\mathbf{P}$ & $\mathbf{R P}(\mathbf{I C}$ 95\%) \\
\hline Drinker & & & & & \\
Positive & $4(23.5)$ & $12(76.5)$ & $16(100.0)$ & 0.37 & \\
Negative & $71(40.1)$ & $107(58.9)$ & $178(100.0)$ & & \\
Smoker & & & & & \\
Yes & $19(59.0)$ & $13(41.0)$ & $32(100.0)$ & 0.01 & $1.72(1.20-2.45)$ \\
No & $56(42.4)$ & $106(57.6)$ & $132(100.0)$ & & \\
\hline
\end{tabular}

$p \leq 0.05$ statistically significant difference. RP $\leq 1$ risk. Yates correction for continuity of chi-square test.

\section{DISCUSSION}

Among the 194 participants, 65 (33.5\%) were PPD reactors on the first test. The others (119) were submitted to a second test, ten of whom showed to 
be reactors, resulting in a booster effect rate of $12.4 \%(10 / 129)$. Tuberculin test prevalence in two stages corresponded to $38.7 \%(75 / 194)$ reactors.

It was also observed that $184(94.8 \%)$ participants had never undergone a PPD, 6 (3.1\%) had undergone one in the past but were non-reactors and $4(2 \%)$ did not remember.

Women predominated in the study population, in the strong reactor as well as in the non reactor group, however, without statistically significant variation. The median age was 38 years, with a predominance of strong reactors within the age range over 38 years. Among the non-reactors, individuals below this age range predominated, however, without a statistically significant difference.

The analysis of professional activity time showed a median of 7 years, without a statistically significant difference. Regarding coexistence with relatives with tuberculosis, income and the fact of having contact with or having someone with TB at home did not show a statistically significant association.

Experts found a 2.57 times higher infection risk regarding professionals older than 46 years when compared to those between 26 and 45 years old. When comparing professionals with more or less than 20 years of activity, the infection risk got 21 times higher ${ }^{(8)}$.

In a study performed at a general hospital in Montreal, Canada, 38.5\% (196/522) were reactors. At this hospital, circumstances like inadequate ventilation and diagnosis delay were identified as the main factors related to tuberculosis infection ${ }^{(8)}$.

Similar studies involving professionals at Brazilian university hospitals found high percentages of strong reactors, with positivity rates ranging from 40.35 to $52.0 \%{ }^{(6,8)}$.

It is known that frequent contact with patients with tuberculosis increases the risk of acquiring the infection. In order to evaluate this infection risk, a comparative study was performed between nursing professionals and factory employees. The results observed a strong reactor prevalence of $51.5 \%$ in the first group and $16.7 \%$ among factory employees, with an infection risk 3.15 times higher in the nursing professional $\operatorname{group}^{(7,9-10)}$.

Significant factors for positive tuberculin test are related to male gender and work time of more than one year at the hospital. The risk would get higher after a year employment, suggesting that prevention should focus on persons at the start of their career, many of them not infected yet ${ }^{(8)}$.
Studies relate tuberculin test positivity with age, male gender and previous BCG vaccination. Male gender and work type and/or location were independent predicting factors for tuberculin test conversion among employees of a Brazilian university hospital ${ }^{(10)}$

Another study detected an increasing positivity rate $(4.0 \%, 6.4 \%, 13.1 \%)$ among students of a Medical College in Campos, as well as increasing tuberculin test positivity according to professional activity time ${ }^{(11)}$. Moreover, an association was observed between positive tuberculin test and hospital activity time of more than five years, without relation to variables like education level and family income ${ }^{(12-13)}$.

Tuberculin research found a $15.2 \%$ positivity upon admission and $23.2 \%$ after 15 years of work. These results suggest that, despite the age factor, occupational exposure presents a risk for acquiring the infection, and that preventive interventions are fundamental in the professionals' admission period ${ }^{(10-11,13)}$.

Recent conversions and tuberculin rotation could be lower if worker protection measures were adopted in health care establishments ${ }^{(14-15)}$.

During an outbreak research performed at a psychiatric clinic in Rio de Janeiro, between 2001 and 2002, 15 TB cases occurred among 374 interned patients and 4 cases among 200 other professionals who worked at the institution's first aid department. Among the other health professionals, a tuberculosis infection positivity of $36 \%(46 / 127)$ was found ${ }^{(16)}$.

There exists important evidence concerning nicotine addiction as a risk factor for pulmonary as well as intrapulmonary tuberculosis. The cough that smokers usually present is a bacillus spreading factor, as there exist studies associating passive exposure to cigarettes with the occurrence of active pulmonary tuberculosis in infected contact children ${ }^{(17)}$.

In the present study, when comparing exsmokers and non-smokers (132/194) to smokers (32/ 194), a statistically significant association was observed between the smoking habit and a positive tuberculin test result $(p=0.01)$, with smokers presenting a 1.72 higher chance of reactivity ${ }^{(17)}$.

\section{CONCLUSIONS}

Tuberculosis prevalence among health professionals is strongly related to the presence of patients with tuberculosis in the hospital environment, 
reflecting the epidemiologic reality of tuberculosis within the community.

The implementation of administrative measures, among which the tuberculin test, are a priority when considering the increase in the total number of patients interned in hospital beds with tuberculosis, in association to HIV/AIDS or other immunosuppressant illnesses, as well as in the detection of resistant strains.

Urgent discussions are needed within health care establishments, calling attention to the need for tuberculosis biosafety as a technical standard and tuberculin screening in the academic training period and in newly admitted health care personnel, besides the implementation of research lines regarding infection risk evaluation in health professionals, validating the adopted measures and its efficacy cost. It is also considered important to use different training strategies, always trying to find out the factors involved in non-adherence to respiratory protection strategies within health environments.

\section{REFERENCES}

1. Hijar MA, Procópio MJ, Freitas LMR, Guedes R, Bethlem EP. Epidemiologia da Tuberculose: importância no mundo, no Brasil e no Rio de Janeiro. Pulmão 2005; 14(4):310-14.

2. Sociedade Brasileira de Pneumologia e Tisiologia. II Diretrizes Brasileiras para Tuberculose. J Bras de Pneumol 2004;30(1):86.

3. Vendramini SHF, Villa TCS, Santos MLSG, Geraldes MSC Aspectos epidemiológicos atuais da tuberculose e o impacto da estratégia DOTS no controle da doença. Rev Latino-am Enfermagem 2007 janeiro-fevereiro; 15(1):171-3.

4. Hino $P$, Santos CB, Villa TCS, Muniz JN, Monroe AA. Tuberculosis pacientes submitted supervised tratament. Ribeirão Preto- São Paulo- Brazil. 1998 and 1999. Rev Latino-am Enfermagem 2005 janeiro-fevereiro; 13(1):2731.

5. Kritski AL, Dalcomo MP, Souza RB, Hollanda T, Filho PPG, Melo FAF. Tuberculose entre profissionais de saude: risco ocupacional? J Pneumol 1993; 19(2):113-21.

6. Franco C, Zanetta DMT. Tuberculose em profissionais de saúde: medidas institucionais de prevenção e controle. Arq Ci Saúde 2004; 11(4):244-52.

7. Rezende MR, Sinkoc VM, Garcia MT, Moraes EO, Kritski $\mathrm{AL}$, Papaiordanou MO. Indicadores relacionados ao retardo do diagnóstico e medidas de precauções para aerossóis entre pacientes com tuberculose pulmonar bacílifera em um hospital terciário. J Bras de Pneumol 2005; 31(3):225-30.

8. Brito RC, Gounder C, Lima DB. Drug-resistant Mycobacterium tuberculosis strains isolated at an AIDS reference center general hospital in Rio de Janeiro. J Bras Pneumol 2004; 30(4):335-42.

9. Centro de Vigilância Epidemiológica. Manual de Atualização: treinamento nas técnicas de aplicação e leitura do teste tuberculinico. São Paulo (SP): Centro de Vigilância Epidemiológica; 2001.

10. Costa PA. Avaliação da infecção tuberculosa em internos de Medicina da Universidade Federal Fluminense. [Dissertação]. Niterói (RJ): Faculdade de Medicina/ UFF; 2000 .
11. Schwartzman K, Loo V, Pasztor J, Menzies D. Tuberculosis infection among health care workers in Montreal. Am J Respir Crit Care Med 1996; 154:1006-12.

12. Costa e Silva R, Ferreira MS, Gontijo Filho PP. Fatores de risco para um teste cutâneo tuberculínico positivo entre funcionários de um hospital universitário brasileiro. J Pneumol $1988 ; 24(6): 353-6$

13. Soares L, Mello F, Kritski A. Prevalência da prova tuberculínica positiva entre alunos da Faculdade de Medicina de Campos, RJ. J Bras de Pneumol 2004; 30(4):440-7.

14. Almeida RM. Avaliação da prevalência e dos fatores de risco para infecção pelo Mycobacterium tuberculosis através de teste tuberculínico em profissionais de saúde. [Mestrado]. São Paulo: Universidade Federal de Säo Paulo. Escola Paulista de Medicina. Doenças Infecciosas e Parasitárias; 2001. 100 p.

15. Pinheiro ACC, Elizardo RM. [resultados preliminares] Avaliação do impacto das medidas administrativas na infecção tuberculosa em profissionais de saúde do Hospital Universitário Clementino Fraga Filho (HUCFF). 2004. [Acesso em 20 jan. 2005]: Disponível em http://www.sigma.ufrj.br/ UFRJ/SIGMA/jornadaIC/publicacao_foco/trabalhos/ consulta/relatorio.stm?app= JIC_PUBLICACAO_TRABALHO \&ano $=2004 \&$ codigo $=276 \&$ buscas_cruzadas $=O N$.

16. Castrilho AOD. Impacto del aislamiento y la quimioprofilaxis en el control de la tuberculosisen el Hospital Psiquiatrico de La Habana 1990- 1999. Rev Panam Infect $2004 ; 6(2): 12-6$.

17. Gajalkshmi V. Smoking and mortality from tuberculosis and other diseases in India: retrospective study of 43000 adult male deaths and 35000 controls. Lancet 2001; 362:507-15. 